\title{
Napier, Palmerston and Palmella in 1833: The Unofficial Arm of British Diplomacy
}

\author{
Andrew Lambert \\ King's College London
}

Captain Charles Napier's service in the Portuguese Civil War combined a brilliant individual performance in the service of the Portuguese Constitutional Party with a vital contribution to the furtherance of British policy.

\section{The British Problem}

In the long eighteenth century, relations between Britain and Portugal were based on the interconnected interests of trade and strategy. Britain had long maintained a leading position in Portuguese commerce: exchanging woollens for wine, and in return providing security guarantees. The relationship was essentially symbiotic, as occasional attempts to alter it invariably revealed. While Britain was the more powerful, her need for the trade of Portugal and her empire, and access to the vital strategic harbour of Lisbon, were of such importance that Portugal could expect help in times of crisis, even if her government did not require it.

This relationship became more complex in the 1820 s and early 1830 s, as the old consensus at the heart of Portuguese politics, a politics complicated and

How to cite this book chapter:

Lambert, A. 2017. Napier, Palmerston and Palmella in 1833: The Unofficial Arm of British Diplomacy. In: Harding, R and Guimerá, A (eds.). Naval Leadership in the Atlantic World. Pp. 141-156. London: University of Westminster Press. DOI: https://doi.org/10.16997/book2.n. License: CC-BY-NC-ND 4.0 
compromised by the long years of war and the loss of Brazil, began to fracture. ${ }^{270}$ Following the death of King Joao VI in 1826, his elder son Dom Pedro, the Emperor of Brazil, had renounced the throne in favour of his daughter Donna Maria, and issued a constitutional charter. Donna Maria was to marry Pedro's younger brother Dom Miguel, the Regent, when she came of age. In the event Miguel, who had already attempted to assume power in his father's lifetime, encouraged by his mother, reneged on the agreement. The charter was unpopular in Portugal, and alarmed the King of Spain, who had his own problems. In 1828, after Prime Minister Wellington had removed the British troops sent by Canning in 1825, Miguel returned to Portugal, and broke his oath to Dom Pedro by proclaiming himself King. Miguel had the support of the great mass of the people, the clergy and the aristocracy. Wellington was preparing to recognise Miguel, if only for the sake of Portuguese stability and British influence, but the Whigs, influenced by Portuguese liberals, loathed Miguel and attacked Wellington's policy.

Before any decisions could be taken Wellington's Ministry was defeated, and replaced by Earl Grey's Whig/Liberal coalition in late 1830. The new foreign secretary, Lord Palmerston, was Canning's political heir. While he was unable to act against Miguel, British resources being stretched by the Belgian Crisis and other concerns nearer to home, Palmerston declared that he would not give Miguel's regime official recognition. Palmerston favoured the use of force, and lending support to the Constitutionalist movement led by Dom Pedro, since April 1831 the former Emperor of Brazil. However, Prime Minister Earl Grey was not prepared to go so far. Grey disliked Pedro as much as his brother. ${ }^{271}$ Furthermore the majority in cabinet were opposed to any overt action, while the Tory opposition, led by Wellington, marshalled an impressive assault on the ministers over this issue. The impasse led to a marked reduction in British influence in Portugal and Spain, reopening concerns over the increasing penetration of French trade in the hitherto largely British-controlled Portuguese market.

The domestic politics of the Reform Crisis would exert a powerful influence over policy towards Portugal, as would the concurrent crisis in Belgium, and a marked deterioration in Anglo-Russian relations after the Polish Revolt. Palmerston favoured a change of regime in Lisbon, but could not secure it by force, not least because of the complex relationship with the emerging Orléans regime in France. Consequently, he and Grey could only offer covert aid to the Pedroite invasion of the Azores, and then the landing at Oporto, which they were prepared to disavow in Parliament. The key intermediary between Palmerston and the Constitutional Party was Marquis Palmella, who was often in London. He worked on Palmerston's fears of another war across the Iberian peninsula, with the concomitant rise in French influence, to secure concessions, including the release of embargoed ships and men destined for the Constitutional forces. Unfortunately Palmella, among the most advanced members of the liberal coalition, was not trusted by Pedro. Consequently, while British policy-makers 
favoured the liberals generally, they were almost equally anxious to promote the cause of Palmella.

In the spring of 1832 Grey agreed to increase the naval force stationed in the Tagus, ostensibly to deter Spanish intervention in support of Miguel. Still optimistic, Palmerston hoped this would secure the success of the Constitutionalist attempt at Oporto. Instead Pedro and his troops were trapped in the city, besieged by a larger Miguelite army. Portugal had not risen to be liberated; if anything the war confirmed the popularity of Miguel, who, for all his personal failings, espoused many of the core values of a proud people. Attempts to resolve the problem by bringing Spain to support the Constitutional case were doomed by the equally troubled succession crisis then looming in Madrid, where the imminent death of King Ferdinand would place his infant daughter on the throne, while her uncle tried to establish a superior claim. ${ }^{272}$

By mid-1833 British government policy was in tatters, condemned in the House of Lords. Fortunately the House of Commons supported the ministers, but that was only a breathing space. Palmerston was close to despair. Anticipating that the final defeat of Dom Pedro was imminent, he instructed the Admiralty to send additional ships into the Douro, to protect British lives in case Oporto fell to a Miguelite assault. The Miguelite foreign minister Santarem was advised that any interference with the British ships would be deemed casus belli. ${ }^{273}$ These were desperate times, and they called for desperate measures and desperate men to execute them.

\section{Charles Napier}

The British problem would be solved by an unusual hero. Captain Charles Napier RN even looked unusual:

'about 5 feet 8 inches in height, spare made, black hair and whiskers, straight nose, and sallow complexion, and fifty years of age. There was no regard to personal appearance, but he looked most intent on what he was about. ${ }^{274}$

Napier (1786-1860) had earned a brilliant reputation in the Napoleonic wars and the War of 1812. He combined seamanship, daring and initiative in the best Royal Navy tradition with a mastery of coastal and amphibious warfare. His quickness of perception and extensive study, allied to intuitive understanding and coolness under fire, revealed a true 'genius' for war. The coming of peace left little scope for such skills, and after marrying and conducting a 'Grand Tour' Napier had sought new challenges in cutting-edge technology and commercial speculation. Between 1820 and 1827 he committed his prize fortune to creating a flotilla of iron steam vessels, providing a commercial service on 
the River Seine. The financial failure of this venture forced him to return to the Royal Navy, and to seek another fortune.

In mid-1832 Napier had just paid off the frigate HMS Galatea, and was seeking a new field of endeavour. He contested the Parliamentary seat of Portsmouth as a radical, knowing that success would give him a claim on the government for a post or some other preferment. In the event he was defeated by powerful vested interests, the local brewer and the leader of the Baring family. Defeat and consequent financial losses forced him to solicit rewards from his government. ${ }^{275}$ It also led him to offer his services to the Constitutional Party in Portugal.

Napier had little choice but to become a mercenary; there was simply no other career open to him. Not that the choice was an easy one; under the Foreign Enlistment Act he risked losing his commission, and with that his naval career. The choice was eased by his own knowledge of, and sympathy for, the Constitutional cause. Napier had twice obtained personal experience of the political problems of Portugal while commanding HMS Galatea. In mid-1829 he had been sent to Lisbon to demand redress for various offences committed by the Miguelite regime. In mid-1831 he was in the Azores to protect British interests during the Constitutionalist conquest of the islands. He conducted the latter task with a marked partiality towards the invaders.

In August 1832 Napier wrote to Marquis Palmella, then in London, offering to command a converted East Indiaman in the Constitutionalist fleet. Such extemporised warships, converted from the largest merchant ships, were often used when regular fighting ships could not be obtained. Palmella was delighted with the offer, having already decided to buy such a ship. If Napier would serve under Captain George Sartorius RN, the current Constitutional commander, he would be most welcome: 'nothing could be more fortunate for the cause of Portugal than to secure your services, even for a short time. ${ }^{3}{ }^{27}$ From this point Napier was involved, initially assisting Palmella to equip the 800-ton Indiaman, Lord Wellington, renamed Dom Pedro.

While Napier had no desire to supplant Sartorius, an old friend, he was soon being invited to take over the chief command afloat. The fact that Sartorius was several years junior to Napier on the Navy List would have made their working relationship difficult had he remained. Sartorius was a brave and skilful seaman, but he lacked the touch of brilliance required, being too methodical and calculating for such fluid circumstances. Furthermore, Sartorius was having a hard time dealing with the complex factional politics of the Pedroite regime at Oporto, and mounting insubordination of his unpaid, unruly British sailors. Nor were his officers any help; at least one of them had been promised the command by elements at Pedro's headquarters. Unequal to the stern task of imposing discipline on officers he did not trust and seamen with whom he sympathised, Sartorius was never going to win the war. While he had defeated the Absolutist fleet in two battles, these were mere tactical triumphs that produced 
no strategic consequences. He needed to capture the entire fleet to secure any strategic benefit. Finally, when he failed to support a combined attack at Oporto in January 1833, due to bad weather, Dom Pedro lost all faith, and sent officers to arrest him at the fleet anchorage at Vigo. Forewarned by Napier, Sartorius turned the tables, calling on the crews of his ships to arrest the ministerial officers, and hold them as security for the back pay owed to the fleet. This confirmed his decision to resign.

However, Napier was not going to serve for honour, or glory. He was effectively bankrupt, and his name was his last commercial asset. Consequently, he drove a hard bargain, and held out for his terms. In part his demands reflected the strictures of the Foreign Enlistment Act, but his personal financial needs overrode other concerns. The negotiations ran from late 1832 to 1 February 1833, when the Chevalier Lima was authorised to offer him the command. Palmella had introduced Napier to Lima, the 'Official' representative of the Constitutional cause in London. Their negotiations resulted in the award of six months' advance of pay, an insurance policy on his life for $£ 10,000$ and similar terms for his officers. Advised to bring his own officers, Napier took his stepson and a handful of hand-picked junior officers and warrant officers to command the ships of his new fleet. ${ }^{277}$

The overriding attraction of Napier to his new employers was the bold and immediate course of action he had proposed to Palmella some months before. He advocated staking the whole war on a single throw of the dice, embarking part of the Constitutional army from Oporto for a bold attempt to capture Lisbon from the sea. With the Constitutional forces pinned down in Oporto, Napier's proposal was attractive, and he was initially promised 12 steamships and 7,000 troops, typically unrealistic figures. Napier advised that if a smaller force were used it should be sent to attack coastal areas. The strategic basis of his thinking was clear: 'the command of the sea is an enormous advantage, and it ought to be used.' ${ }^{278}$

Throughout this period Napier was in close contact with Admiral Sir George Dundas, the second Naval Lord of the Admiralty, and an important politicomilitary figure. Dundas was an old friend and close confidant; he was also the trusted political lieutenant of the First Lord of the Admiralty, Sir James Graham. ${ }^{279}$ Graham had come into contact with Napier back in 1814 , while serving in a diplomatic capacity with Lord William Bentinck in Italy, and formed a very high opinion of him. ${ }^{280}$ When Graham awarded Napier a Greenwich OutPension in 1832 he did so on the express understanding it 'should not deprive the country of the experience and talents of superior officers. ${ }^{281}$ The two men had been corresponding on a range of issues. In addition, the First Naval Lord, Admiral Sir Thomas Hardy, knew Napier well, as did almost every officer in the service. Among Whigs and Liberals he was rated a great man; Tories were less complimentary. More significantly, Graham shared Palmerston's opinion on the problems of the Iberian peninsula. Consequently it can be inferred that 
Napier was neither unaware of the wishes of these two key ministers, nor acting against their privately conveyed opinion. Napier's departure for Portugal with so many officers would have been impossible without the tacit complicity of the ministers, at the very least. He even had to ask Dundas to release his stepson from his studies on board HMS Excellent. ${ }^{282}$

The bright hopes of February were soon dashed by lack of money, and it was only the use of Napier's name that enabled the Constitutional financier Mendizábal to secure the $£ 12,000$ needed to raise fresh troops, seamen and steamships. By early April, Napier's plans to take Lisbon had been reduced to a force of 1,000 men in three steamboats for an attempt on the Algarve. Even so, he would take the post only if Sartorius was satisfied, and the fleet was fit to sail. ${ }^{283}$ Napier was too professional an officer to take excessive risks, and too careful of his own name, his last asset, to hazard it without a good chance of success.

Sartorius was only too pleased to give up his command to a man he knew had the ability and resolve to complete the task. After paying tribute to Napier's 'strict and honourable character', Sartorius informed him of the conspiracies that had ruined his command. ${ }^{284} \mathrm{He}$ expected some of the British sailors would leave, but hoped enough would remain to man the ships, with the Portuguese sailors, who were good and more 'tractable' than the English. The Portuguese officers he condemned as 'ignorant and spiritless', save a few of the youngest. He would remain at Oporto only long enough to hand over the squadron. In the interval he prepared his men for the arrival of their new Admiral, 'a Black looking shabby fellow' Napier was advised to bring out signal flags, battle lanterns and quill tubes. ${ }^{285}$

To disguise himself from the prying eyes of his Tory opponents at home, Napier adopted the nom de guerre Dom Carlos de Ponza, in honour of an outstanding amphibious operation he had conducted back in 1813. His officers were more pedestrian, picking alternative 'British' names.

On 22 May, Napier boarded the steamer City of Waterford at Spithead, only to find the newly raised sailors mutinous, having been misled by the crimps. A further mutinous outbreak at Falmouth resulted in several men being drowned when the boat in which they were attempting to desert capsized. It was hardly the most auspicious start. Recognising that he was now an Admiral, Napier left the imposition of order and discipline to Commander Wilkinson, his Captain of the Fleet. Wilkinson applied the lash with some severity, and quickly imposed control, although he could not achieve a willing or rapid execution of duty. Napier finally departed on 2 May, with five steamers, but only 137 seamen, rather than the 400 he needed to complete the crews of the fleet. He was also suffering from an agonising neuralgia that would plague him for the next month. He was accompanied by Palmella and Mendizábal. ${ }^{286}$

After a brief stop at Vigo, where hopes of reinforcement were disappointed, Napier arrived off Oporto late on 2 June. After meeting Sartorius and then 
going ashore to meet some of his acquaintances from the Azores in 1831, Napier was given a shabby reception by Dom Pedro. Pedro disliked Palmella and had not been told of the expedition. His entourage even implied Palmella was coming to remove him! Disgusted at this treatment and prevarication among the Emperor's advisors over the expedition, Napier threatened to leave. ${ }^{287}$ His temper, never the best aspect of his complex character when on shore, was not improved by the neuralgia, or the fact that he had burnt his mouth so badly on a supposed remedy that he could not speak. ${ }^{288}$ The threat quickly had an effect. Pedro improved his manner, and won over Napier, an easy man to flatter and given to admiring 'great men'. The Emperor accepted that something had to be done soon, and this sparked a strategic debate at headquarters. On 11 June Pedro ordered that an army of 2,600 men be embarked on Napier's fleet, under the Duke of Terceira. ${ }^{289}$ Palmella would accompany the expedition to govern any liberated territory. Mendizábal was also on board. No target was assigned; all would be left to the commanders on the spot. Marshal Solignac, the French general then commanding at Oporto, and the chief opponent of the expedition, finally resigned on 12 June. He had argued for a direct attack across the Douro, but had been opposed by Marshal Saldanha who preferred Napier's move to the south. Even the removal of the French general did not end the prevarication; army headquarters held up the embarkation of the troops, prompting Napier to signal ashore that he would resign if the embarkation did not resume with immediate effect. He had to repeat himself the following day to get the fleet watered. Napier was particularly anxious to move because he had intelligence that the enemy were about to send their fleet to sea.

Napier's arrival had an almost immediate impact on the Absolutists, who began to shift their heavy baggage towards Lisbon on 14 June. ${ }^{290}$ The ministers at Lisbon closed the Tagus to all ships at night the same evening. ${ }^{291}$ As Napier had observed, seapower, in the right hands, was a powerful force. In Lisbon Lord William Russell, the British envoy-in-waiting, saw in the arrival of Napier the resignation of Solignac and the impending movement of the Absolutist fleet, evidence that the crisis of the war had arrived. ${ }^{292}$

The majority of British officials and individuals resident in Portugal, diplomats, merchants and naval officers, were opposed to the Miguelite regime. Consequently, Napier received priceless intelligence from at least two sources. As Britain had not recognised the Miguelite regime, the Acting Consul General, Richard Belgrave Hoppner, was effectively the British diplomatic representative in Lisbon. ${ }^{293}$ Known to be an ardent supporter of the Constitutional cause, Hoppner served from early 1831 until mid-August 1833, when Russell, who had been resident for some months, presented his dormant credentials as Special Envoy. ${ }^{294}$ Hoppner's hatred of Miguel reflected a liberal revulsion at his overthrowing the constitution, his infamous personal conduct and arbitrary tyranny. ${ }^{295}$ 
Before leaving England, Napier had requested Hoppner provide him with detailed information on the sea defences on the Tagus, with a view to a naval attack. Hoppner was pleased to further 'the cause of Right and Justice', providing a very full description of the defences. He had witnessed the French attack in 1831, and reported trifling losses on both sides. He was also aware of a strong feeling in favour of the Constitutionalists among the troops manning the forts, while the Miguelite ships were miserably manned and would, he expected, simply be filled up with pressed watermen and other unfortunates when they had to go to sea. ${ }^{296}$

Hoppner's blatantly partisan behaviour had proved to be a thorn in the side of the altogether more discreet naval commander at Lisbon, Rear Admiral Sir William Parker. Parker's small but powerful force had been sent to protect British commercial interests, and deter other powers from intervening, notably Spain. Although a Whig and disgusted by the conduct of the Absolutists, Parker was too professional to exceed his orders in public. Consequently, while his private feelings were all on the Constitutional side, ${ }^{297}$ he was criticised by Hoppner and the Pedroites. This criticism was wholly unwarranted. Parker was secretly supplying his fellow countrymen in Dom Pedro's fleet with intelligence. Parker had admired Sartorius's conviction and commitment, but he recognised that Napier was his superior: 'as courageous as he was shrewd', Napier understood 'more of the strategy of war' than any man he had ever met. ${ }^{298}$ Parker provided Napier with details of the state and movements of the Absolutist fleet, whose arsenal was in clear view of his flagship. ${ }^{299}$ Nor was this his only intelligence source. He was also able to read most of the Miguelite telegraph messages coming into Lisbon. 'We are masters of many of the secret keys', he told Graham, 'and feel confidence, therefore, in the greater part of these communications. ${ }^{300}$ As Lord William Russell explained, the telegraph cypher was constantly changed, 'but always bought for a few crowns. ${ }^{301}$

Throughout the tortuous business of bringing Pedro to take the risk of an expedition, Napier kept Admiral Dundas informed of every step, and enjoined that his letters should be sent on to Lord Palmerston. ${ }^{302}$ The Admiralty building was, after all, only 100 yards from the Foreign Office. The overriding issue, as he constantly reminded Dundas, was to secure British recognition of Donna Maria. ${ }^{303}$

Even with the troops on board, Napier had further problems: 100 of the British seamen who had been serving under Sartorius insisted on going home. Consequently, he had to rely on Portuguese seamen to man some of his squadron, concentrating the British hands on the key ships, under his best officers. Further punishment was necessary before he could instil any order and energy into his crews.

The squadron comprised:

Don Pedro: ex-Indiaman 50 guns (short 18-pounders \& 32-pounder carronades), 317 men 
Rainha frigate: Flagship (ex-Argentine, ex-Swedish af Chapman of 1803) 42 guns (18-pounders), 300 men 'including Portuguese'

Donna Maria: 40 guns (short 18-pounders), 254 men

Villa Flor: 18 guns (18-pounders)

Portuense: 20 guns (32-pounder carronades), 126 men, 'half Portuguese $^{304}$

Three or four hired steam ships: City of Waterford, William IV, Birmingham (Names uncertain) $)^{305}$

A transport/hospital ship

Total manpower on the sailing warships was no more than $1,000 .{ }^{306}$ The first three ships were largely manned with British seamen.

Against this force, the intelligence Napier had received suggested the Miguelites would send two battleships, two frigates and a number of smaller craft. He knew one battleship was a rotten old tub, hardly fit to go to sea, and that many of the men had been pressed.

On 20 June the expedition set off, with so few troops Napier decided that an attack on Lisbon was not possible. This was fortunate, for his plans had been widely discussed in the English newspapers. ${ }^{307} \mathrm{He}$ would have been pleased to hear that his actual destination, the Algarve, was still a secret, to the best of Parker's knowledge. ${ }^{308}$ It may be that the open discussion of a direct attack on Lisbon was a ruse. If so, it was highly effective. On the night of 22 June, the entire garrison of Lisbon was kept in arms, ready to respond to a landing, while the key position of Fort St Julian's was reinforced..$^{309}$ Risings at St Thomar and elsewhere on the Tagus added to the worries of the Lisbon ministers. ${ }^{310}$ Once at sea, the army was hidden from the Absolutists, and could land anywhere. They could not hope to be strong enough everywhere, and elected to reinforce the centre. In fact they had chosen the wrong place.

Reaching the Algarve, the troops landed at Cacellas, close to the Guadiana River, late on 24 June, meeting hardly any resistance. The Constitutionalists occupied Faro on 27 June, and Lagos on 30 June, where they paused to establish local administration, recruit volunteers, add to their stores and prepare for the next move. Napier hurriedly wrote to inform Parker that he planned to sail to the Tagus, lash his steamships alongside and enter Lisbon at night: 'I wish you would give me your opinion of what I might expect from such an attempt.' ${ }^{311}$

The Absolutist Fleet:

Dom Joao (74) Flagship Commodore Aboim

Rainha (74)

Princessa Real (52) frigate

Martim de Freitas (49) ex-east Indiaman

Cybele (26) large corvette 
Princessa Real (24) large corvette

Isabel Maria (22) large corvette

Tejo (20) brig

Audaz (20) brig

One xebec

Total: $3,400 \operatorname{men}^{312}$

When the Absolutist ships left the Tagus, Parker recognised the crisis was at hand. He knew Napier's force was much weaker than the Absolutist squadron, not least from the wreck of a schooner at Peniche with 80 priceless British seamen on board, who were now prisoners at Peniche and in Lisbon. However, he was confident Napier would 'achieve everything that is practicable. ${ }^{3.13}$ His main concern was to be ready to respond to the result of the battle that he and Russell agreed was 'inevitable. ${ }^{314}$ For the next fortnight, the British representatives in Lisbon followed the progress of the Constitutional forces from the Absolutist telegraph. ${ }^{315}$ When the Constitutional force landed in the Algarve, the Absolutist ministers finally roused themselves to act, sending their squadron to sea. However, Hoppner for one doubted that the squadron meant business:

'It is not supposed to be Commodore Aboim's intention to engage the ships from Oporto, but merely to cruise and interrupt any other troops that may be sent from thence to reinforce and support the expedition of the Duke of Terceira; nor is it improbable that the object of the Government in sending him to the Southward was only to keep their enemies in check by his appearance off the coast, and prevent their advance into the interior, until they could assemble a sufficient force to oppose their march upon the capital. ${ }^{316}$

Napier put to sea on 2 July with the six sailing ships, which now included a 6-gun schooner that had joined the squadron at Faro, but she would play no part in the battle. He left the steamers to complete their fuel and follow them to Lisbon. At 8 am the following morning he caught sight of the Miguelite fleet off Cape St Vincent, and sent the Villa Flor back to Lagos for the steamers. He spent the rest of the day keeping between the enemy and Lagos Bay, to ensure the junction of his forces, which occurred at $5 \mathrm{pm}$. The Absolutist fleet was sailing in a tight formation, with the two battleships and two frigates in one line, the three corvettes and two brigs in line behind them. Such evidence of seamanship demonstrated that the enemy was not incompetent. The two squadrons remained within a few hundred yards of each other throughout the night, Napier looking for a favourable opportunity for battle, preferably under the land, where the sea would be calm. This manoeuvring for position continued throughout the day, to the growing impatience of the British sailors, 
used to simpler tactics, and simpler officers to conduct them. Napier explained to the men that he was looking for a favourable opportunity, and used the intervening hours to improve gun drill, especially fighting both broadsides at once. Throughout the two days in contact the enemy:

'shewed no disposition to bring us to action: we dared risk nothing till the weather became sufficiently fine to make one desperate effort to save Portugal or lose the cause. ${ }^{317}$

Recognising he could not win an artillery duel, and would not obtain the necessary political impact even if he did, Napier had always planned on boarding the enemy ships, either at anchor in the Tagus or on the open ocean. He was playing for the highest stakes; he had to capture the enemy fleet, not win a tactical victory. He recognised Sartorius had achieved nothing with his battles. On the morning of 5 July, Napier's experience led him to anticipate that the weather, which had hitherto been too boisterous for a boarding action, would improve. He called the steamship captains to confer on board the flagship at 10 am, planning to use their ships to tow his warships into action. His plans were ruined by the refusal of the engineers to go under fire without a bonus of $£ 2,000$ a man. Before he had time to lament the lost opportunity, he was saved by the timely intervention of nature. The beginnings of a breeze were stirring from the north, and Napier, who was to windward, immediately shifted his plan to attack under sail. He then mustered his men on the upper deck, and gave them one of his characteristic fighting speeches, full of prize money, home and sweethearts. The men were also fed, for Napier knew that British seamen cared more for a full stomach than anything else.

The tactics of the battle were predetermined, and reflected Napier's experience. He knew that his smaller and weaker ships would be able to close more safely from astern, as long as they were sufficiently well handled to avoid the broadsides of their opponents. He had intended to attack the enemy flagship, Dom Joao, with his own ship, but she was ahead of the other 74, the Rainha, which he now elected to attack with his own ship and the Dom Pedro. This left the Dom Joao without an opponent, although he hoped to capture her with his own ship once the first 74 had been taken. As they went into action he instructed Captain Peake of the frigate Donna Maria to employ the same tactics against the Princessa Real. The Portuense and Villa Flor would attack the Martim de Freitas. Napier left his two small Portuguese-manned ships to do what they could with other Absolutist vessels. He knew the key to success would be the British officers, and the experienced seamen who followed them, aboard his three largest units. He took care to explain his plans to his officers.

When the anticipated breeze arose, around $2 \mathrm{pm}$, Napier led his fleet into action, heading directly for the 74-gun Rainha de Portugal. The Absolutists held their fire until the range came down to musket shot, about 100 yards, and 
then opened a heavy and rapid, but largely inaccurate, barrage. Outstripping the rest of his force, Napier's Rainha closed on the enemy stern, where few guns bore, and manoeuvred to yaw across her quarters, firing effective broadsides into her flimsy stern galleries. The skilful direction of the ship under heavy fire was no accident; Napier had done much the same in April 1809, working across the stern of a flying French battleship off Guadeloupe. His skill helped to minimise casualties, as did his ordering the men to lie down to avoid return fire. Even so, three gun crews and a Marine Lieutenant were cut down.

Relying on his final raking broadside to confuse the enemy, Napier ran his ship alongside her higher opponent to board. As he did so, two men standing beside him were killed. The smart seamanship required to secure the ship alongside, and board a battleship from the decks of a frigate, was only to be expected from the hand-picked officers and men involved. Almost the entire crew of the Rainha had been assigned to the three divisions of boarders; the first, led by Napier, went over the gangway; the second, under his stepson and Commander Wilkinson, went up and through the fore chains, while Captain MacDonough, a volunteer, led the third into the aftermost gun port of the enemy main deck. All three groups met stiff resistance. MacDonough cleared the way for his men to board, but was killed in the process. His division quickly drove the enemy up onto the quarter deck, where they met the other two divisions. The second division was held up by spirited opposition, with both officers badly wounded, but after a brief setback when the two ships drifted apart, Napier led his division over the gangway and stormed aft. He sought a quick victory by overpowering the enemy officers on the poop. With most of his men on board, Napier quickly secured the upper deck of the Miguelite vessel; her Captain was killed and the remaining members of the crew were driven below deck, where they surrendered. Although five British officers and six seamen had been killed, and his stepson and his friend Wilkinson were severely wounded, Napier quickly restrained his men. Every British officer who boarded the Rainha had been wounded; three would die, while two more were badly hurt. This was hardly surprising, for as Napier observed, the men did well at the guns, but rather hung back in boarding, needing to be lead from the front. In view of their mutinous state only weeks before, it was a testament to his leadership and training that they did so well.

From the poop Napier hailed Captain Goble on the Dom Pedro, directing him to make all sail after the Dom Joao but, just as he did so, Goble was fatally wounded by a musket ball from the lower deck of the ship Napier had just captured. Despite this, the Dom Pedro pressed on, engaging the enemy flagship from the leeward. Napier, leaving a small party to secure his prize, hastily reboarded his flagship, shifted the tattered remnants of two sails, patched up the rigging and joined the pursuit of the Don Joao. When Napier's flagship ranged up towards his windward side, the Absolutist commander surrendered. Two frigates were also taken before the end of the day, the Princessa Real by the Donna Maria in a near copy of Napier's attack on the Rainha, in which she 
suffered several casualties before luffing up across the enemy stern, raking and boarding from the fore chains, led by five British officers. The Absolutists went below, but fired at anyone trying to follow them, until a pair of 18-pounder guns were shifted from the gunports, loaded with grape, and directed down the main hatch. At this point the Absolutist officers surrendered. The speed and efficiency of the action demonstrated the value of Napier's pre-battle tactical conference. ${ }^{318}$ The American captain of the Martim de Freitas, his ship crippled aloft by her smaller opponents, finally surrendered to the Rainha, which had left the Dom Pedro to secure the second 74. The corvette Princessa Real surrendered the following morning. ${ }^{319}$

The battle, fought seven miles SW of Cape St Vincent, was a triumph of skill, planning and determination over weight of metal and numbers of men. Napier recognised that his advantage lay in the professional core of his fleet, and would be most useful in dynamic circumstances. Throughout the battle he remained absolutely calm, responding to the shifting opportunities of the moment, and exploiting the weakness and errors of the enemy.

For a man credited with such an excitable temperament when ashore, Napier was astonishingly 'cool' under fire. This was the secret of his success in battle: he was not a simple fighting man, but a complex, calculating leader who could control, as far as contemporary technology permitted, the direction and pace of the battle. Despite being under heavy fire, and then in the thick of the handto-hand fighting, seeing his beloved stepson covered in wounds, Napier was always the Admiral, never abandoning his command responsibility to take up the simple task of individual combat. Nor did he allow the battle to end until he had no chance of taking the last enemy vessels.

That night Napier secured his prizes and made sail for Lagos, where he cast anchor the following morning. Once the fleet was secure, he wrote to tell his wife he was safe. He concluded, with characteristic brio: 'I think the prize money will be something handsome. You must give a dance on the green and think of me. ${ }^{320}$ He provided Parker with two accounts, the first a breathless résumé, the second a more 'professional' appreciation. Napier reported 25 killed and 92 wounded, with enemy casualties of 77 killed and 105 wounded. ${ }^{321}$ These were severe losses, which had occurred on only four ships. Later critics would carp at Napier's triumph, claiming the enemy had been bought, or did not fight. Such slurs were unwarranted: Napier and his officers won the battle by a combination of skill, resolve and leadership. They also paid a high price for leading from the front: hardly a man among them was not wounded, while eight of the 25 killed were officers. ${ }^{32}$ Their blood secured the Constitutional victory.

In the hour of triumph, Napier did not forget the political purpose of battle. Nor did Russell:

'The morning after we heard of it Admiral Parker and myself called Viscount Santarem, and told him that, in our opinion the issue of the contest was decided by this blow. 
The two British officials then delivered the same message to the pro-Absolutist Spanish minister. ${ }^{323}$ Russell was so excited by what Parker termed a 'brilliant achievement' that, just for once, he forgot the proper decorum, referring to 'Admiral Napier' in an official letter. ${ }^{324}$

Napier's letter to Admiral Dundas, intended for Palmerston's eyes, also urged that the opportunity was now right for the ministers to recognise Donna Maria. ${ }^{325}$ The same day, the Admiralty removed his name from the Navy List, and cancelled his Greenwich pension following Lord Londonderry's attack in the House of Lords, because he was 'absent without leave.. ${ }^{326}$ They could do no less, under existing rules, but took care to do no more.

In the interval between the battle and the arrival of news in London, Palmerston reflected on the importance of the Portuguese crisis:

'We really ought to take some line upon this business. The failure of Pedro would be a great blow to our Power both at home and abroad, but more especially would it affect us in all our foreign relations. ${ }^{327}$

On 14 July his mood changed when Chevalier de Lima showed him Napier's letter of the $6^{\text {th }}$. Palmerston hurried to inform the Prime Minister and pass the news to the First Lord of the Admiralty. ${ }^{328}$ Political problems at home and abroad would be greatly simplified by this timely triumph. Recognising that Napier had won a great victory in the struggle between the autocratic eastern powers and the western liberals, Palmerston quickly sent the news to his ambassador in Vienna, to ensure that the reactionary leader Prince Metternich, who had long sponsored Miguel, was made aware of his defeat. 'Carlos de Ponza forever! Was there ever a more gallant exploit in the annals of seamanship?' he declared. ${ }^{329}$ Even so, hesitation in the cabinet, and Earl Grey's continuing hostility to Pedro, delayed British recognition of Donna Maria.

Napier's success was particularly welcome at the Admiralty, which was under severe pressure to find the ships to support British foreign policy, without having to go back to Parliament for more money. Graham was delighted:

'I have just seen Lima's account of the success of de Ponza: the moral effect of the victory will be great, I should think almost decisive and I sincerely \& warmly congratulate you. ${ }^{330}$

The Absolutists evacuated Lisbon on 24 July, after Terceira had marched to the Tagus and defeated the Miguelite army in a battle that was decided when their general was killed.

Napier had sent the Donna Maria to blockade the Tagus as soon as she was ready, prompting some concern in Britain, and began beating his way north with Palmella and the bulk of the combined squadrons. However, the fleet was delayed by an outbreak of cholera, and then becalmed in Cascaes Bay on 22 July. 
Nevertheless, his impending arrival and a liberal rising in the city completed the collapse of Miguelite morale. Parker, by now able to show his true feelings rather more openly, signalled the news that the city had declared for the Queen to Napier as he was trying to beat his way up river. ${ }^{331}$ The fleet arrived off Black Horse Square on 25 July.

For Palmerston, and William IV, the occupation of Lisbon by the Queen's forces, and the fact that 'the whole of the naval force of Portugal is now serving under her flag', were the key reasons for renewing diplomatic relations, suspended by the usurpation of Dom Miguel. As long as nothing unexpected had occurred in the interval, Russell was to activate his dormant commission, and recognise the Queen. He was then to read the Constitutional ministers a lecture on the need for conciliation of the defeated, and the avoidance of problems with Spain. In exchange, he could inform them that a powerful force of British troops and ships had been assembled at Cork, to be despatched to Lisbon if any foreign power attempted to support the usurper. ${ }^{332}$ In the hour of triumph Palmerston had not forgotten the commercial purpose of British policy, the particular relationship that existed between the two countries, or his fear that Dom Pedro's ministers were either corrupt or pro-French, or more likely both. He still favoured a government led by Palmella, which was exactly what Pedro did not desire. As soon as he had reached Lisbon, Pedro had dismissed Palmella.

With the Constitutional Party occupying the city, Russell consulted Parker, who agreed the time was right to extend British recognition. ${ }^{333}$ Once Spain changed sides, removing all support from Miguel, the war in Portugal was effectively over. ${ }^{334}$

With Lisbon in Constitutional hands and Napier dominant at sea, Parker's force of three battleships would be perfectly adequate. ${ }^{335}$ The British government would not need to ask Parliament for additional naval estimates. The Belgian crisis was already settled, so the resolution of Portugal essentially settled the liberal character of western Europe, and would place Britain 'in a condition to talk boldly to Russia' over her treatment of Poland. ${ }^{336}$ Napier, having contributed so much to this result, was now a name to be reckoned with. He would be used to frighten the reactionaries for the next two decades.

Two months later, Sir James Graham had occasion to reflect on this new reality, and on the man behind the triumph:

'The whole letter breathes the character of the man, daring, intelligent and dauntless; but he is not to be trusted implicitly, except in the hour of danger, and then he performs prodigies far beyond all calculation.' ${ }^{337}$

One of his fellow mercenaries showed a deeper insight into this most complex of warriors. 
'Napier was a slovenly-looking man; his trousers, for instance, had evidently once been white, but were now the worse for wear, and had become a brown yellow. He was fond of saying eccentric things, and of pretending to be in a great passion; while it was evident he was merely affecting it in words and manner, and had all his wits about him. Although he wished to be thought impelled by romantic feelings to help a young Queen to her throne, still it was not difficult to see that no man ever entered on an enterprise with more cool calculation than he did before agreeing to lead this expedition, or more resolved to be well paid, alive or dead, by prize money or insurance. ${ }^{338}$

Another eyewitness at Oporto recorded:

'Napier was the most egotistical, selfish man I ever knew, but clever and brave. He never wrote or spoke well of any one with whom he served.'339

For all that these criticisms contained more than a grain of truth, it is doubtful if anyone else could have achieved so much in such a short space of time. The seamless manner in which Napier had dovetailed the needs of his new masters with the wider ambitions of the British ministers was a work of genius. That he discussed the whole process with ministerial, diplomatic and naval confidantes throughout demonstrates a strategic vision of the highest order. Sir William Parker was right; he really did understand more of war than any man alive. In the space of a single month Napier had transformed the course of a war that had been running for years.

Napier was careful to secure the prize money for the ships taken in his battle, reckoned at $£ 130,000$, for himself and his followers. In addition, he was given two Portuguese titles, an estate, a pension and back pay. The Portuguese war transformed his prospects: he began it as one of any number of penniless naval captains; when he returned home he was the most famous naval officer alive, and had the money to buy a fine estate. These were the tangible rewards of a job well done. His success captured the imagination of a nation, and the attention of key statesmen, most notably Lord Palmerston. He was returned to the Navy List in 1837, and went on to gather further glory. Nor had he finished with Portugal, but that, as they say, is another story. 